\title{
老年者胃潰瘍の研焭
}

\author{
歖识市立大学医学部第二内科 \\ 守一雄, 柏木 政伸, 井上幸愛 \\ 玉田得三郎，曰井孝，大塚 啓子 \\ 山屋 禃男, 藤島智, 白木 洋二 \\ 平山静策 \\ 神杂川景立成人病センター内科 \\ 上田 昭夫 \\ 横活南共済病院内科 \\ 䈨光
}

\section{STUDIES ON GASTRIC ULCER IN THE AGED}

Kazuo Mori, Masanobu Kashiwagi, Koai Inoue, Tokusaburo Tamada,

Takashi Usui, Keiko Otsuka, Sadao Yamaya, Satoru Fujishima,

Yoji Shiraki, and Shizue Hirayama

The Second Department of Internal Medicine, Yokohama City University, School of Medicine

\section{Akio UEDA}

The Department of Internal Medicine, The Center for Adult Diseases, Kanagawa

Hikaru EBrRA

The Second Department of Internal Medicine, Yokohama Minamikyosai Hospital

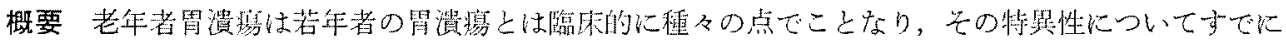

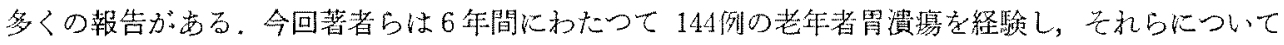

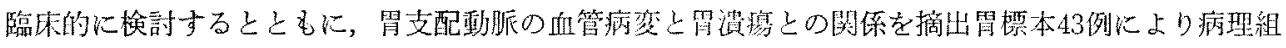

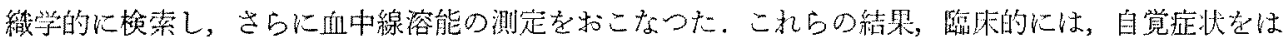

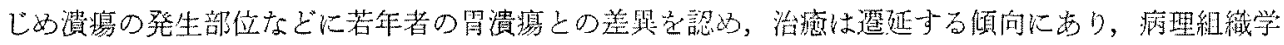

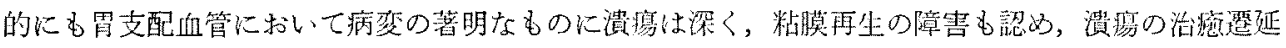
の一因として，動脈硬化による血管病変の役割について考察した。
\end{abstract}

\section{I. 緒訔}

1853年Virchow ${ }^{1)}$ により胃潰㾴の血行障害説が

[昭和 45 年 12 月 25 日受稿]

な技，本諭支の要旨は，第3 回世界消化器病学会， 第53回, 54回日本消化器病学会総会, おょび第12回日 本消化器病学会秋期大会に战いて発表した。

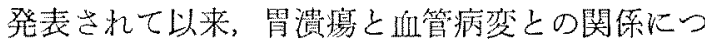
いて多くの報告があり，また臨床的には，老年 者に打ける消化性潰湯は若年者のそれとはことな り，1948年Spang2)らにより，小わゆる“Altersulkus”としての報告を爻てよりその特異性につ き多くの業績がみとめられる。加れわれはすでに 
老年者の胃病変について若年者との差異につき検 討してきたが，今回，胃病变のうち局所の血行障 害をはじめとする血管病変が，胃溃瘍の臨床像お よび経過にいかに影響をもたらすかを追求するた め, 臨床的に, 病理組織学的に検討し，さらに血 中線溶能を測定した。

\section{I. 臨床的観察}

\section{1. 観察対象}

対象は，昭和38年より昭和43年までの6 年間 に，当内科に入院または外来にて加療し確実に経 過を追求しえた老年者胃潰癔患者で，年令60才以 上 144例（男子80例，女子64例）である。な和対 照情方以下の 387例（男子 246例，女子 141 例)である（表 1)。

\section{2. 検查項目}

これらにつき，i）初䛦時の自覚症状，ii）臨

表1。年命分布

\begin{tabular}{|c|c|c|c|}
\hline \multicolumn{4}{|l|}{ 知察対象群 } \\
\hline 年令一住别 & 男 & 女 & 竍 \\
\hline $60-69$ & 56 & 44 & 100 \\
\hline $70-79$ & 23 & 19 & 42 \\
\hline $80 \sim$ & 1 & 1 & 2 \\
\hline 部 & 80 & 64 & 144 \\
\hline \multicolumn{4}{|l|}{ 对照群 } \\
\hline 年命 珄别 & 男 & 女 & 部 \\
\hline-19 & 19 & 9 & 28 \\
\hline $20-29$ & 45 & 25 & 70 \\
\hline $30-39$ & 54 & 18 & 72 \\
\hline $40-49$ & 62 & 39 & 101 \\
\hline $50 \sim 59$ & 66 & 50 & 116 \\
\hline 部 & 246 & 141 & 387 \\
\hline
\end{tabular}

表 2 .切除胃の病理組織学的检素

\begin{tabular}{|c|c|c|c|c|}
\hline \multirow{2}{*}{ 年合 } & \multicolumn{3}{|c|}{ U1 分 曙 } & \multirow[b]{2}{*}{ 尌 } \\
\hline & II & III & V & \\
\hline $60-64$ & 2 & 17 & 6 & 25 \\
\hline $65 \sim 69$ & 1 & 8 & 4 & 13 \\
\hline 70 - & 0 & 2 & 3 & 5 \\
\hline 影 & 3 & 27 & 13 & 43 \\
\hline
\end{tabular}

床検查成績，iii）治癒経過，iv）他臟器の血管病 変と治瘾経過との相関などについて検討した。

\section{III. 病理組織学的観察}

1. 観察対象

対象は60才以上の胃潰瘍患者で, 昭和40年 1 月 より，昭和 45 年 1 月まで当内科で経過をみたもの を中心に，当大学外科，神奈川県立成人病センタ 一、横浜南共済病院で手術を行なつた摘出胃標本 の43例である．年令は60才より76才にわたり，男 子31例，女子12例である(表 2).

2. 検查項日和よび検查方法

i ) 潰瘍深達度

ii ）潰瘍粘膜再生度

いずれも切除された胃に扎いて，潰瘍をできる だけその中央面できり，組織標本をつくり，潰瘍 の深達度をUl分類にしたがつて観察した。また 再生粘膜を程度により, 次のごとく4群にわけ た。

I 群 : 全再生, II 群 : 再生良好

III群：再生不良, IV群：再生なし。

iii）胃支配動脈との関係

これら標本切片中にふくまれ，胃壁浆膜面をは しる太さ $1,000 \sim 2,000 \mu$ 動脈之，胃壁内で潰 瘍底よりできるだけ遠ざかつた部位で太さ 200 $\mu \sim 800 \mu$ の動脈の二種類の血管を選び，それら を招の打の壁外動脈，壁内動脈とし，これを正円 になるようにさりだし，ocular micrometerをる ちい，血管断面にて中膜外層間之内膜内層間の距 離を測定し，それぞれ外径，内径として動脈狭少 度を下記により測定した。

$$
\text { 動脈狭少度 }=\frac{(\text { 外径 })^{2}}{(\text { 内径 })^{2}}
$$

\section{IV. 線溶能測定}

1. 観察対象

昭和 44 年 4 月より昭和 45 年 3 月までの当内科外 来を受診し, 胃 X線検查, 胃内視鏡にて胃潰瘍を 確認した60才以上の男子16例，女子8 例の計24例 であり，対照群としては同年代の潰瘍をもたない 健康老人15例である．また潰瘍を有寸るるのの5 ち, 潰舅が再燃, 再発をくりかえし，1力年以上 
表 3 、楾溶能測定

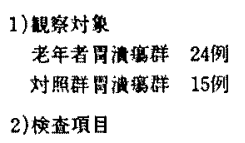

i) euglobulin lysis time

ii) fibrin 平板滰解面杪

iii) fibrinogen 定量

にわたる経過をるつものと， 1 年末満の 2 群にわ け検討した（表 3).

2. 検查項目括よび検查方法

いずれも下記 3 項目について検討し，空腹時に 測定した。

i) euglobulin lysis time

euglobulin試験管にeuglobulin（以下eu-g 略

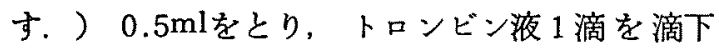

し， $37^{\circ} \mathrm{C}$ の佰温槽にてeu-gの溶解時間を 30 分間隔 にて測定した.

ii ) fibrin平板溶解面積

fibrin平板にeu-g $0.03 \mathrm{ml}$ を滴下し， $37^{\circ} \mathrm{C} 18$ 時 間放置し，溶解能の面積を測定した。

iii) fibrinogen定量

Plasma $0.5 \mathrm{cc}$ 大り生食水にて稀釈後 $60 \mathrm{v} / \mathrm{cc}$ thrombin $0.1 \mathrm{cc}$ を混じ, ${ }^{1} / 10 M-\mathrm{CaCl}_{2}$ を加光， $37^{\circ} \mathrm{C} 30$ 分後, fibrin塊をとりあげ, $30^{\prime}$ 乾燥後科量 した.

\section{臨床的観察}

老年者胃潰瘍は全消化器疾患者の約 $3 \%$ にあた り，全胃潰瘍患者の約 $25 \%$ であつた。

i) 初診時の自覚症状：自覚症状としては, 心䆟部痛が一番多かつたが，吐血，下血の出血を 主訴として来院したものは，老年者では $30.5 \%$ と 対照群の $19.4 \%$ にくらべて高率をしめし，うち吐 血については老年者 $13.5 \%$ ，対照群 $8 \%$ ，下血は 老年者 $17 \%$ にたいして対照は11.4\%であつた. ま た心窩部痛をはじめとして, 吞酸, 食欲不振, 体 重減少，胸やけ，腹部膨満などの症状は対照と比 較してすくなくなかには注とんど自覚症状をる たずに偶然に発見されたものも少なくなかつた (表 4).
表 4. 初喰時症状 (\%)

\begin{tabular}{|c|c|c|}
\hline 淀状 & $\begin{array}{c}\text { 若 年 者 } \\
\text { (59才以下) }\end{array}$ & $\begin{array}{l}\text { 老年者 } \\
\text { (60才以上) }\end{array}$ \\
\hline 心初部椨 & 84.6 & 49.7 \\
\hline 频出血 & 19.4 & 30.5 \\
\hline 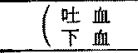 & $\begin{array}{r}11.4 \\
8.0 \\
\end{array}$ & $\left.\begin{array}{l}17.0 \\
13.5\end{array}\right)$ \\
\hline 琶心，㗪吐 & 25.0 & 33.0 \\
\hline 在 酸 & 25.0 & 19.2 \\
\hline 食欲不层 & 16.3 & 14.0 \\
\hline 体重減少 & 16.3 & 14.0 \\
\hline 胸やけ & 21.2 & 8.7 \\
\hline 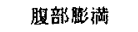 & 26.6 & 8.7 \\
\hline
\end{tabular}

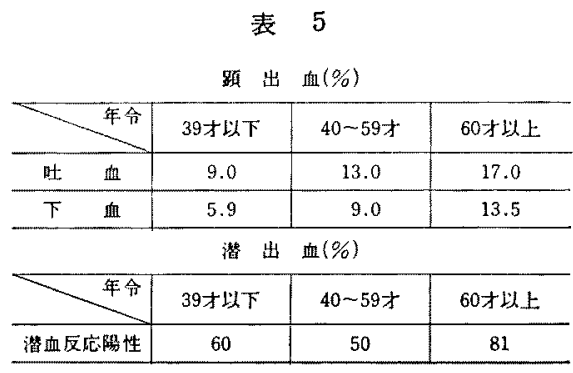

ii ）臨床検查成績 :

a）便潜血反応；上記のように顕出血のみ られたあのをふくめ,ピラミドン法,ベンチシンン法 により便潜血反応をみると，対照では約半数が陽 性を示すが，老年者では $81 \%$ と陽性率はたかい．

b）末梢血液検査；検血にて過半数に筫血 を認め, 赤血球数 200 万台以下のものが $34 \%$ に認 められた。（表 5)

c）胃液酸度；胃液の検査にはカフンイン 法をもちいた．60才以上という生理的な老化現象 からも低酸を示す傾向はあるものの,60\%が低酸, 無酸を示し, 過酸, 正酸を示したものは39才以下 では浪全例，40～59才では50\%，老年者では40 \%にすぎなかつた（表6）。

d）潰瘍の発生部位および性状，レントゲン 検査, 内視鏡検査の結果検討すると，39才以下で は胃角部，幽門前庭部市わせて約 $90 \% ， 40 ５ 9 才$ では幽門前庭部は少なく, 胃角部, 胃体部あわせ て68.2\%となるが，60才以上では胃体部のみで60 $\%$ ，胃角部をあわせ93.6\%と大部分であり，高令 


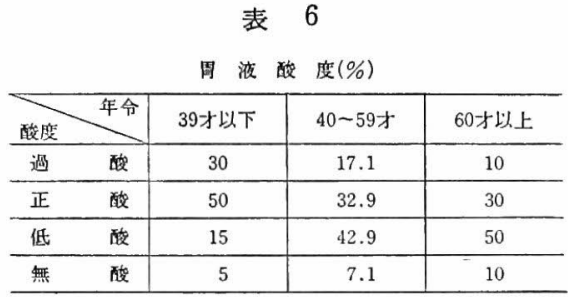

表 7

㴮琴発生部位(\%)

\begin{tabular}{|c|c|c|c|}
\hline 年命 & 回 体部 & 四角 部 & 幽阿前庭部 \\
\hline 39才以下 & 10.3 & 55.6 & 34.1 \\
\hline 40 - 59才 & 32.3 & 35.9 & 11.8 \\
\hline 60才以上 & 60.4 & 33.2 & 6.3 \\
\hline
\end{tabular}

になるにしたがつて潰瘍の発生部位は噴門側に移 行する傾向を認めた，潰瘍の大きさについては， 初診時, $\mathrm{X}$ 線写真にて直径 $1 \mathrm{~cm}$ 以上のものがかな

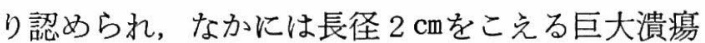
をみた症例もあつたまた潰瘍はほとんどが単発 であつた（表 7 ）.

iii）治療経過について, 諸種薬物, 生活の規 正, 食事療法などで治療をおこなつたが, 入院加 療によるものと, 外来通院によるものと多少条件 はちがってくるが，当内科にて加療をはじめてか ら, 治療に協力的であり, 十分に経過を和觉た症 例について検討すると，レントゲン検査上ニッシ エの消失, 内視鏡的に上皮化をもつて治癒として 治㾍日数をもとめてみると, 老年者の平均は86日 でなかには 7〜8カ月に执よぶものもあり, 著者 らは一つには動脈硬化による胃粘膜への血行不全 を考觉, 動脈硬化との関係についてさらに検討し た.

iv）他臓器の血管病変と治癒日数との関係

a) 大動脈との関係, 胸部 $\mathrm{X}$ 線写真による大 動脈との関係については, 大動脈横径, 大動脈胸郭 比（A T R）との関係をみた。 大動脈横径は平均 $5.9 \mathrm{~cm}$ であり, 大動脈胸郭比は $21.3 \%$ であり, 潰 瘍の治癒日数との関係については, 大動脈横径に ついては，幅の拡大とともに治療日数は延長を認 め, 大動脈胸郭比については，たかい值を示すほ

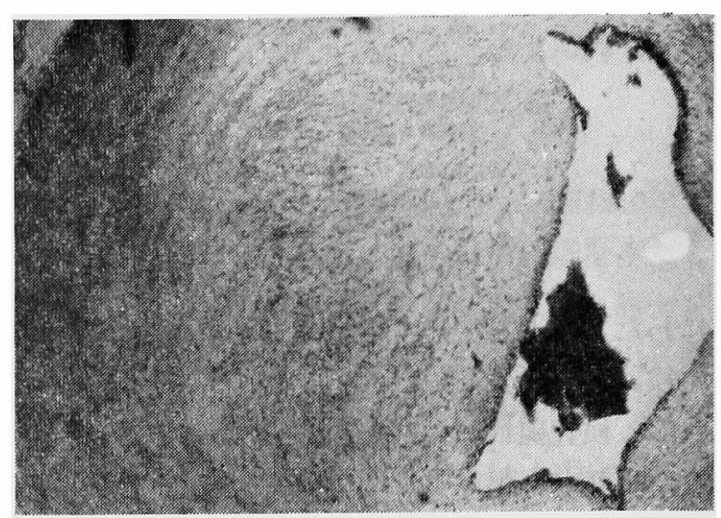

写真 1

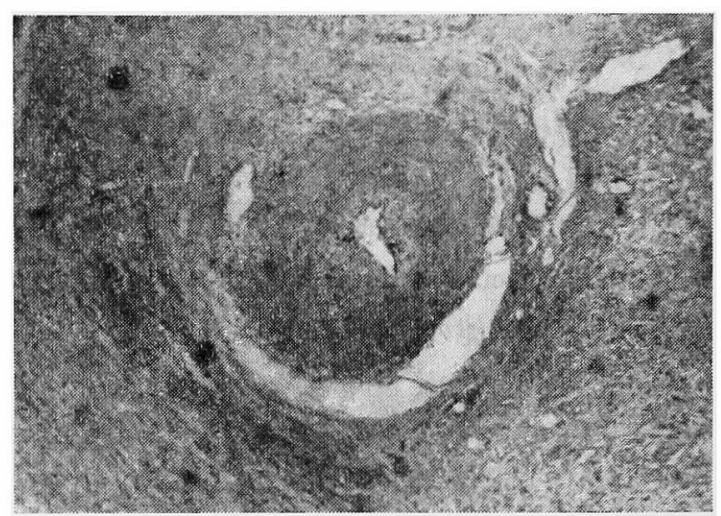

写真 2

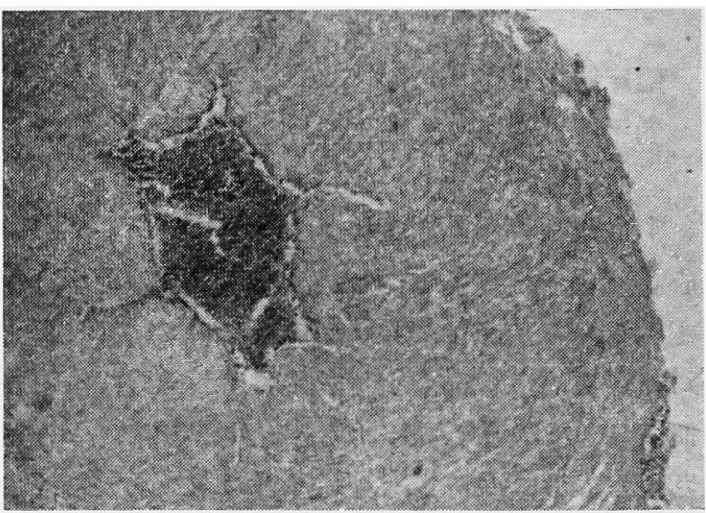

写真 3

ど治瘉日数が延長する傾向があるよらに拈もわれ る.

b ）その他, 心電図変化との関係については, 
S T， T変化をはじめとする動脈硬化（冠動脈硬 化）としての変化を心電図にみる例では，潰愃の 平均治癒日数は 109日，とくに心電図に異常の認 めない例では平均58日と差をみとめ，7 カ月，8 カ月の経過をみた症例ではいずれも心電図上冠動 脈硬化をおもわせる所見を認めた。

\section{病理組織学的観察}

45例中, 潰瘍の発生部位は, 胃体部31例, 胃角 上部 4 例，胃角部 8 例，幽門前庭部 2 例，吻合部 1 例で，胃体部が68.8\%とるつとも多い，次いで 潰瘍の深達度は手術例を対象としたためもあり， Ul I はなく， Ul II が 2 例, Ul IIIが28例, Ul IVが 15例であり，1例をのぞきすべて単発例であつ た，潰瘍の深達度と動脈硬化との関係について は，壁外動脈では，Ul II の 1 例は動脈狭少度（以 下狭小度と略す，）は2.5と低いＵ1 IIIでは狭少 度 5 以上は24例中 10 例の $42 \%$ であり，7をこえる ものは8例の33.3\%であるＵ1 IVでは，狭少度

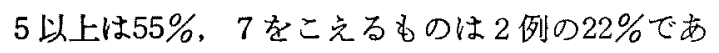
る.

写真 1 は64才，女子 深達度U1 IIIの潰瘍があ り，動脈狭少度12.8を示した血管病变である（図 1).

次に壁内動脈の変化と深達度については, 図 2 に示すごとくで，U1 II ではいずれも狭少度は 5 以

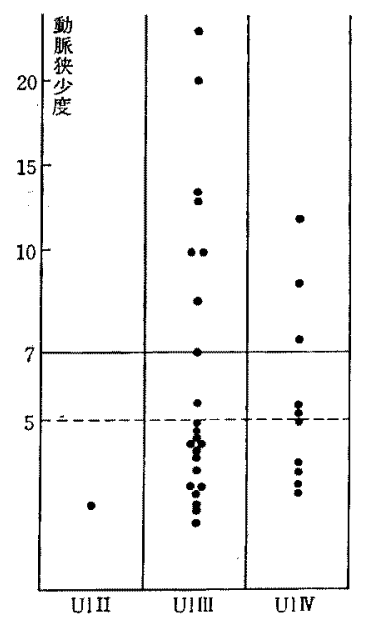

図 1. 深達度と動脈凑少度壁外動脈 $(300 \sim 2000 \mu)$

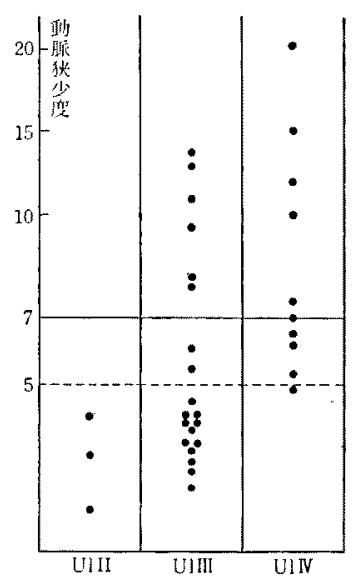

図 2，深達度と動脈少度壁内勘脈 $(200 \sim 800 \mu)$

下であり, U1 II では狭少度 5 以上は20例中 8 例の 40\%，7以上は6 例の30\%である.U1 IVでは狭 少度 5 以上は10例中 9 例の $90 \% ， 7$ 以上は 5 例の 60\%であり，血管の変化が著明となるにつれて深 達度は增加するよらに招もわれる。写真 2 はU IVの潰瘍をすつ66才，女子の胃壁内動脈の所見 で, 動脈狭少度は27.0であつた。

粘膜の再生度と血管病变について：壁外動脈 では, 全再生例 2 例中 1 例は狭少度12.5とたかい が，再生良好群では㹨少度 7をこえたものはな く，5以上は17\%にすぎず，再生不良群では 5 以 上は18例中 9 例の $50 \% ， 7$ 以上は 8 例の $44 \%$ であ り，再生のみられなかつた群では，“狭少度 5 以上 は 5 例中 3 例の $60 \% ， 7$ 以上は $40 \%$ であつた。 写 真 3 は粘膜再生の不良であつた60才の男子の胃壁 外動脈の変化であり, 狭少度は23.7 高值を示し た. 壁内動脈と粘膜再生の程度についてみると, 全再生群 3 例中 2 例は狭少度は小さい，再生良好 群に沶いては, その 9 例中 7 例が狭少度 5 以下 で, 7 以上のbのはない，再生不良群では15例中 7 例をこ光るものは8例の56\%，5以上は10例の $66 \%$ ，全く再生の認められない群では 5 以上は 80\%，7以上は40\%で狭少度はいずれも大きい (図 3,4 ).

つまり, 動脈硬化による血行障害が，深達度拝 


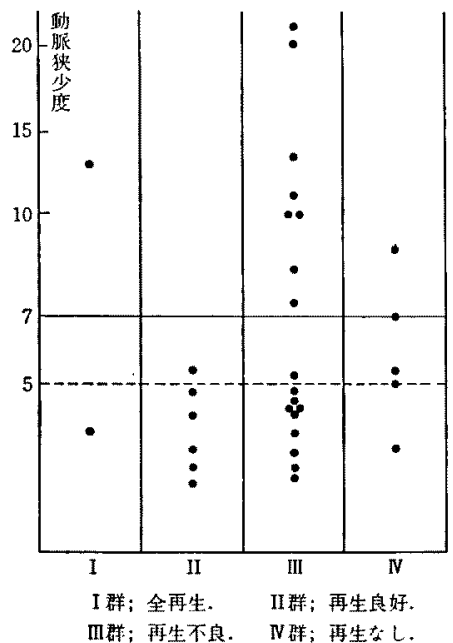

因 3，粘瞙再生之動脈浃少度壁外動脈 $(800 \sim 2000 \mu)$

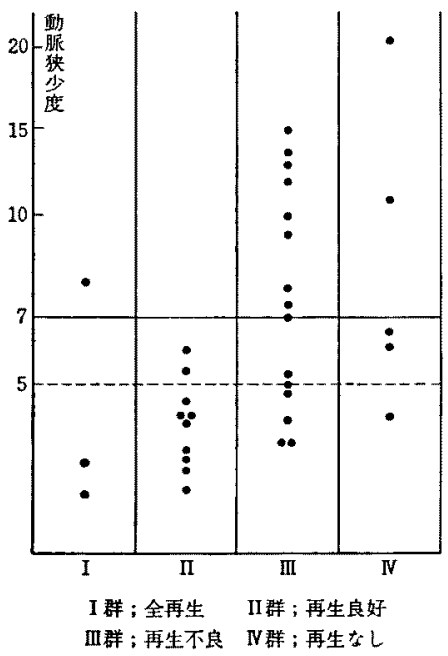

図 4. 粘膜再生と動眽狭少度壁内動眽 ( $200 \sim 800 \mu)$

よび粘膜再生にある影響を及ぼすと考えられる。 以上動脈の狭少度が 7 以上のものは全例中 $30 \%$ で あつたが，個々についてみると，深達度にかんし ては全例がUI III, UIIVの群に含まれ，粘膜再生に かんしては12例中 1 例を除き11例が再生不良，再 生のみられなかつた群に属していた。

\section{線溶能について}
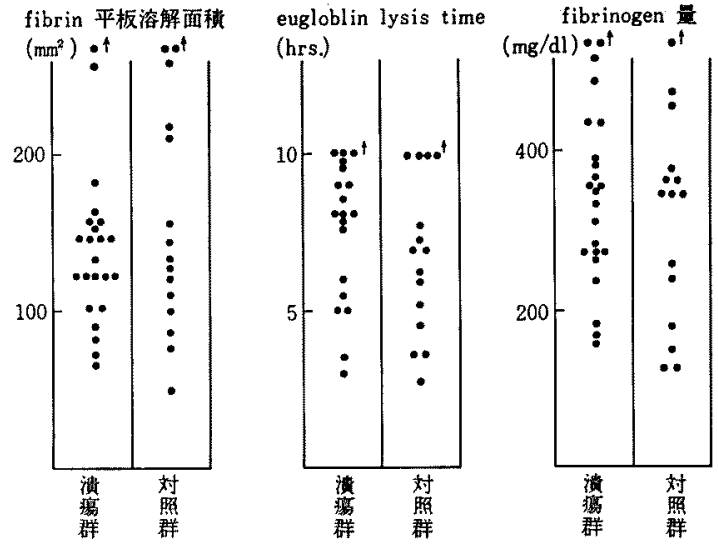

図 5,老年者胃潰㾝上楾溶能
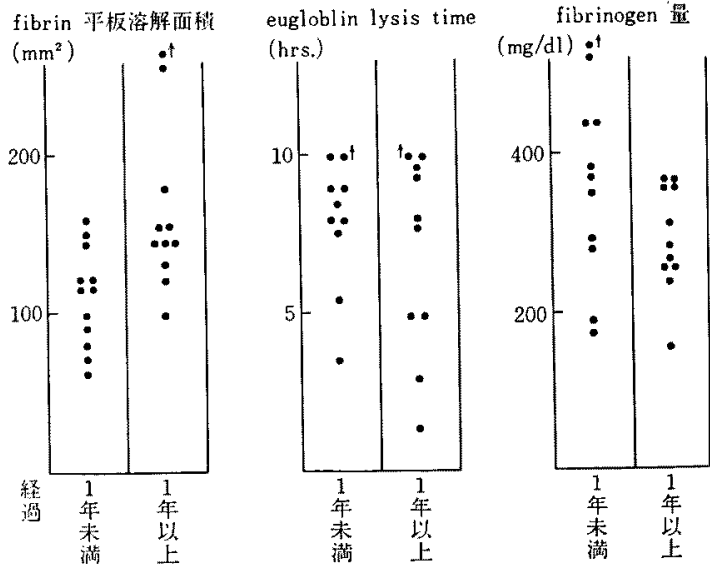

図6、難治性潰瘍の線溶能

図 5 は老年者の胃潰瘍を有するものと，同年代 の潰瘍のない健康者との比較である，eu-g溶解面 積, fibrinogen量などは多少の差はみられるもの の，いずれる正常範囲内である，ただfibrin平板 溶解面積については，潰瘍を有する群の平均 154 $\mathrm{mm}^{2}$, 対照群平均 $162 \mathrm{~mm}^{2}$ といずれも亢進してい た. また潰瘍の治㾑期間との関係については，1 年以上の経過をもつ群と，経過の 1 年末満の 2 群 について検討すると図 6 のごとく，1 年以上の群 では， 1 年未满の群に比して，fibrin平板溶解面 積は平均 $190 \mathrm{~mm}^{2}$ と大きく, eu-g溶解時間は平均 1 時間の短縮をみ, fibrinogen量については 1 年 末満の群の平均 373mg/dlにくらべ 296mg/dl と減少 
していた。

\section{VI. 考 案}

消化性潰渴は老年者においても決してまれな疾

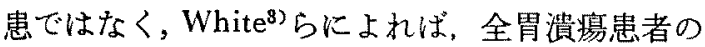
らち，60才以上の老年者では臨床的には約 $10 \%$ ， 剖検所見では64\%と高值を示すとし，本邦に扣い

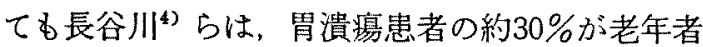
であると報告している，また老年者胃潰瘍は若年 者のそれに比較し，異つた臨床像を示し，その特 殊性については1948年 Spang ${ }^{2) ら を は し め と し て ~}$ 諸家の報告がある，著者らは144例の症例につき 臨床的に検討したが，このような時,これらがい ずれるいわゆる“Alters-ulkus”で老年期に入つ て発症したものであるか，あるいはそれ以前より 再然，再発をくりかえしていたものであるかが問 題となろら，著者らは既往症などに注意し，若年 よりつついているとかんがえられる症例は除外し 検討した．臨床症状，臨床所見をあわせてみる と，他疾患においても一般に老年者にみられるよ 5に，症状はあまり定型的な像をしめさず，ほと んどの症例で自覚症状に乏しいのに対し，若年者 にくらべ出血を主訴として，あるいは検査にても 出血を認めることが多いのは諸家の成績とほぼ同 様であつた，また潰瘍の発生部位は，若年者に比 較して角上部，胃体部に多くみられることは長谷 川らの報告にもあるように特徽であるう。これに は，幽門腺，胃底腺の境界域の問題も考虑しなけ ればならないが，一方高命者でもあり，血管病変 との関係も検討してみると，胃体部小弯，幽門部 の動脈は末梢間に相互の連絡がそしく，機能的終 動脈であり，その部を支配する血管の動脈硬化性 の病変による血行障害も考慮する必要があると思 われる．事実，潰瘍の附近において組織学的にか なりの血管の病変がありこれが潰瘍にたいして 一次的の変化が，二次的の変化かについても疑問 があり，後述するよらに，時には潰瘍の発生原因 の一つとも思われるが，いずれにせよここれらの 血管病変による血行障害は，その支配下にある潰 瘍の治癒経過に何らかの影響をもつものと思われ
る。また胃動脈の病変は臨床的に確認しがたく， 他藏器の血管変化と潰瘍の経過との関係は興味あ るところであり，以前教室の上田らは老年者の胃 病変に報告したときに，家鬼で，ラノリン，エピ ネフリン負荷により実験的に動脈硬化症を作製し たが，このとさ胃動脈にも血管病変をみとめてお り，臨床的にもある程度の関係はあるとかんがえ られる，著者らの検討した症例でる大動脈，心電 図などに動脈硬化性病变を思わせる変化をみとめ た症例に抢いて治痛の遷延する傾向にあり，眼底 変化，腎機能について車同様の傾向があるょらに 思われた。

摘出標本により潰瘍底部における血管変化につ いて検討するに，それが潰瘍の原因となるか，結 果として発生したものであるかがやはり問題であ る。1853年Virchow ${ }^{1)}$ の報告以来，わが国でも長 与, 本田 ${ }^{6)}$ ，江口らの業績があり，江口，長与ら

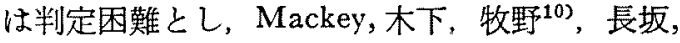
滰田 ${ }^{11}$ らは続発したものとかんがえている，しか し，これらの指摘している動脈病変はいずれも潰 癔底部附近に限局したものであり，Hauser ${ }^{5)}$ ，江 口らのいうごとく閉塞性動脈内膜资，血管壁の炎 症細胞浸潤，動静脈の血栓形成牤よびその組織化 である。また津山らは年令を問わず，潰瘍底部に 病変はなくても，はるか隔つた部位にみとめた動 脈内膜肥厚を潰瘍の発生原因とかんが之, 福田 ${ }^{12)}$ らは胃潰瘍の発生原因となる血管病変と, 胃潰癔 による続発性血管病変は区別できるものとかん がえ，胃壁外動脈の主体をなす硬化性変化は顕 微鏡下にはJoresのいう elastische hyperplastische Intimaverdickungに一致した内膜肥厚としてみら れるという，薬師寺7) らる良性腎硬化症に合併せ る胃潰瘍には，腹胫動脈から左胃動脈末梢にいた る強い動脈硬化を生じ，これは全周性の内膜肥厚 と，内膜内より内膜外筋内にひろがるびまん性の elastofibrosisであり，しかも侵されるのは常に内 $1 / 2$ で，外 $1 / 2$ は変化が少なく，潰痬の原因病変と主 張している，著者らはとくに壁内動脈の検討にあ たり潰瘍より遠い部位をえらび，潰瘍に上る二次 
的変化と考之られる血管病変はできる限り除外し た．動脈硬化の程度を表現する方法としては， Goreをはじめとする種々の方法があるが，胃動 脈の変化が内膜だけでなく，中膜の肥厚も2とめ られることなどにより，松岡 ${ }^{32}$ ，津山92らによる 動脈狭少度をるちいた。こ机によると狭少度が7 以上に達すると血行障害は著明となるとし， 5 以 上のものを有意義としている，今回は，摘出胃標 本のため，胃支配血管についてさらに起始部への 検索はできなかつたが，結果は壁外動脈につい ては，U1 III で㹨少度 7 をこえるものは33\%，U1 IVでは $22 \%$ で 7 上のbのについてみるとUIII <Ul III >UlIVとなるが， 5 以上としてみるとU1 II $<\mathrm{Ul} I I I<\mathrm{UI}$ IVの順となる．ついで壁内動脈に ついては，明らかに深達度と狭少度の間には相 関がみとめられた，津山らは「一般に血管変化は 潰瘍が深くなるにつれて多くなり，高度となつて いた」と論じ，牧野は98例の胃潰瘍切除胃につ き，急性，慢性期に分類し，内膜肥厚は慢性期に のみみられると報告しているが，われわれの検索 からも理解されることである，ついで前項にて老 人性潰瘍は臨床的飞治癒が遷延すると報告した が，潰瘍断面に打壮る粘膜再生といら組織学的に みると，再生の良好群に比へ，再生の恶いものに 狭少度は大となる，局所の偱環障害と皟瘍の治癒 ないし進展に関係する因子として江口，本田，牧 野，福田らも重視しているが，著者らの結果もほ ぼ同し傾向を示した。左胃動脈との関保で汸H. Munscheck ${ }^{13}$ はとくに結論は困難としているが， 男全 ${ }^{14)}$ らは，胃小弯側に分布寸る左胃動脈の病 变は胃潰序の際に高度であり，胃壁の粘膜下，筋 層，浆膜下，壁在小動脈の内膜病変も同じょらな 傾向を示し，とにに胃体部に抽ける老人皘㿑例で はこの部の動脈硬化性病変は著明であるとしてい る、著者らは，老年者と比較するため，若年者 14 例について同様の検索を行なつたが，狭少度 7 を こ穴るものは壁内，壁外動脈ともに2例のみです つた，老年者に打いて狭少度 7 以上のものは全体 の約30\%であつたが，その注とんどが粘膜再生不
良，再生なし群であつたこと，潰瘍の深達度に ついては，UIIII，Ul IV群に属していたことなど より，血行障害がなんらかの意味をもつことが考 兄られ興味あることと思われる，消化性潰瘍にお ける血中線溶能については，岡本 ${ }^{15}$ らによれぱ8 例中 7 例の $88 \%$ に元進を認めており，また山形 らはEA C A 滴定法などをもちいて，胃潰序の41 例中18例に活性亢進を認めている．著者らの症例 では，対照との間にそれはど著明な差は認められ なかつたものの，再然，再発をくり返した治癒遷 延例と経過の短かかつた症例の間には多少ながら も差を認めた。しかし，吐血，下血を主訴として 来院した 3 症例についてはフタプリン王板溶解面 積は $440 ， 286,560 \mathrm{~mm}^{2}$ といずれも線溶能の亢 進を認めた，局所線溶能に比べ，血中線溶能は かなりの因子の関与が考觉られ，また対象がいず れも高令者であることなどより，動脈硬化症との 関係にも考虑する必要があるう。つまりDuguid ${ }^{18)}$ の血栓説より発し，Astrupの血液凝固系と線溶系 との動的平衡の立場より, 線溶能 の活性の低下 により過剩な線維素層が内膜面上への形成をみ, さらに内膜深層や，中膜内層への細胞の変性や壊 死をきたしての血管病变の増強とする考えや，さ らにはストレスなどに起因した線溶能の元進は血 管壁の透過性をたかめ，血将浸潤を介しての動脈 硬化の進行に関与するとの五島 ${ }^{17} ら の$ 説もあり， それらの作用にはまだ残された問題がある。いず れにしても線溶能の変動因子の多いことなどを考 克わわ，ここにでてきた成績が，潰瘍のための ものであるのか，㐫いは潰瘍の発生因子，治瘺 遷延因子によるものであるかを理解することはも ずかしく，今後の検討が必要とされる.

\section{VII. 結 論}

著者らは老年者胃潰瘍について臨床的観察，摘 出胃標本による血管病変と潰瘍の関係，さらには 血中線溶能について検討し次の結果を克た。

1）臨床的にみて老年者胃潰瘍は全潰瘍患者の 約25\%に認められた。

2）老年者胃潰瘍は若年者の胃潰瘍に比べ自覚 
症状にそしいが，吐血，下血を主訴とすることが 多い.

3）潰瘍の発生は，胃角上部，胃体部之噴門側 に多くみられ，潰瘍は巨大となり，単発すること が多い。

4）治瘺日数涎長し，他䑏器に動脈硬化性病 変の著明な例に治癒の遷延する傾向がみられた。

5）胃摘出標本については，血管病变の著明な もの（動脈狭少度 7 以上）は約30\%に認められ， 哚達度はU1 III, UlIVの潰瘍であり，粘膜の再生は あまりみられなかつた。

6）再然，再発をくりかえし，経過の遷延した ものに血中線溶能の克進する傾向がみられた。

以上のごとく，老年者胃潰瘍は若年者の胃潰痬 と比較し，元の特異性が多られた。

\section{文献}

1) Virchow, R.. Historisches, Kritisches und Positives zur Lehre der Unterleibsaffektion. Virch. Arch. 5: 281, 1853. - 2) Spang, K.. Das Altersulkus am Magen und Zwölffingerdarm. (Stuttgart. 1948.) -3) White, F.W. and David, J.: The Incidence of Gastroduodenal Ulcer. "Sandweiss Peptic Ulcer" 185, Standers Co., 1951. 一4) 長谷川吉康他：老年者胃潰瘍の辕性，老年病。
3:14, 1958. -5) Hauser, G.: Die peptischen Schädigungen des Magens, usw. Handbuch der speziellen path. Anat. und Hist. (Henke-Cubasch.), Berlin：329，1926. - -6) 本田郁也：急性㕅微性

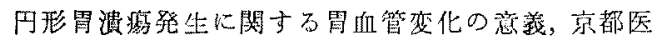

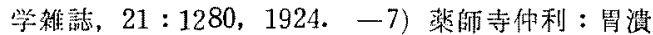
弱の背景之しての腹腔動脈枝の昢脈病变の病理学

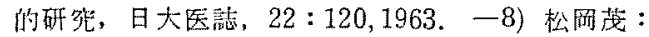
睬動眽硬化症の病理, 最新医学, 11 (4): 780, 1956. -9）津山㹂：慢性胃溃瘳に注ぐ動眽の病理組織学 的研究，長崎医学会教誌, $32: 1497,1957$, -10) 牧野武盛：切除胃の脈管学的砸究，日外会䓌，59：

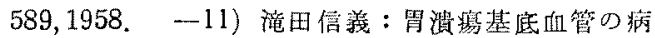
理組緎学的所見, 日新医学, $36: 573,1949,-12$ )

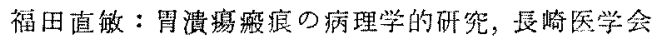
猚誌, $39: 222,1964$. - 13) Munschek, H.: Beziehungen der Sklerose der Arteria gastrica sinstra zur allgemeinen Arteriosklerose. Beitrag zur Pathogenese der Ulcus ventricule und des Altersulkus. Fortschr. Med. 82: 319. -14) 相沢豊 三，男全正三．胃溃癔の成因としての動脈硬化，老 年痌，6:329, 1962。一-15) 网本歌子他：ヒ卜血清

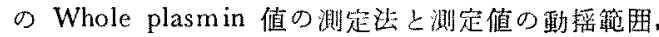
棕合医学, $17: 41,1960$ 。一16) 山形做一：抗プラス ミン療法，339，(昭和43)。一-17) 五島堆一郎：動 脈硬化に拉けるプラスミンの意㼁, 日内会誌, 51 : 850, 1962. - 18) Duguid, J.B. and Robertson, W.B.: Mechanical factors in atherosclerosis, La ncet J. Path. Bact. 64: 523, 1952. 